\title{
WZAJEMNE RELACJE MIĘDZY WOJSKIEM A SPOŁECZEŃSTWEM W GALICYJSKIM GARNIZONIE PRZEŁOMU XIX I XX WIEKU NA PRZYKŁADZIE TARNOWA
}

\author{
Wacław Szczepanik \\ Muzeum Historyczne Miasta Krakowa
}

\author{
ABSTRACT \\ RELATIONS BETWEEN THE ARMY AND THE SOCIETY IN A GALICIAN \\ GARRISON AT THE TURN OF THE $20^{\text {TH }}$ CENTURY: A CASE OF \\ TARNÓW
}

The article discusses the relationships between the Austrian army and the Polish civilian population in Tarnów, where at the turn of the $20^{\text {th }}$ century was stationed a large garrison. There were two regiments (infantry and cavalry), as well as the brigade headquarters, the recruiting district command, the barracks, and the training and auxiliary infrastructure. Tarnów can be considered a representative example of the Galician garrison towns of similar size. Soldiers of the garrison entered into numerous interactions with the civilians. The military participated in state, military and religious ceremonies. They also organized and participated in the carnival balls. The military orchestra played for the civilians on various occasions. Soldiers and officers had social relationships with the civilians. The presence of the troops in the city also prevented frequent cases of public order violation such as fights, thefts or assaults. Soldiers stirred up various, often contradictory, emotions in their civilian neighbours.

Key words: Galicia, Tarnów, military history, daily life.

Słowa kluczowe: Galicja, Tarnów, historia wojskowości, życie codzienne.

W niniejszym tekście pokrótce omówię badania nad wzajemnymi relacjami pomiędzy wojskiem a ludnością cywilną w Tarnowie na przełomie XIX i XX wieku. Postaram się przedstawić całokształt wzajemnych kontaktów między „światami” wojskowym i cywilnym, uwzględniając tezy dotyczące stałych tendencji. Zakres 
chronologiczny niniejszego tekstu obejmuje lata 1894-1914. Cezura 1914 roku nie powinna budzić wątpliwości, ale rok 1894 wymaga wyjaśnienia. Można uznać, że w tym roku austro-węgierski garnizon miasta uzyskał swój ostateczny kształt, wtedy bowiem do Tarnowa przybył sztab i pojawiło się tam większość batalionów polowych 57. Pułku Piechoty. We wcześniejszym okresie jednostki garnizonu i jego liczebność podlegały dość znacznym zmianom, w latach 1894-1914 daje się natomiast zaobserwować swoista stabilizacja.

\section{AUSTRIACKIE (AUSTRO-WĘGIERSKIE) GARNIZONY W GALICJI NA PRZEŁOMIE XIX I XX WIEKU}

Zgodnie z danymi z 31 grudnia 1869 roku w Galicji stacjonowało 22673 żołnierzy austriackich. Do początku XX wieku można było zaobserwować dość stałą tendencję wzrostową, która doprowadziła do osiągnięcia w 1900 roku stanu 70865 żołnierzy. Michał Baczkowski dokonał porównania danych dotyczących tak zwanych śródrocznych stanów osobowych dla lat 1870-1907, dowodząc, że oprócz liczby żołnierzy w Galicji, wzrósł także procentowy udział załogi wojskowej tego kraju koronnego w całkowitej liczebności armii monarchii naddunajskiej. Według jego ustaleń w 1870 roku wojskowi w Galicji stanowili około 10,6\% wojska Austro-Węgier, a w 1904 roku odsetek ten wynosił około 20,1\%. Przy tym zarejestrowano także pewien wzrost liczebności armii - z 250822 żołnierzy w 1870 roku do 297752 w 1900 roku$^{1}$. Baczkowski określa liczbę ośrodków garnizonowych w Galicji w latach 1870-1907 na 43, przy czym część z wymienianych w spisach miejscowości miała załogę wojskową epizodycznie, inne zaś były gminami przyległymi do twierdz i żołnierze tam stacjonujący administracyjnie podlegali pod Kraków, Przemyśl lub Lwów. Garnizony zazwyczaj umieszczano w większych i średnich miastach położonych przy liniach komunikacyjnych (zwłaszcza kolejowych). Liczba żołnierzy w poszczególnych garnizonach Galicji na przełomie XIX i XX wieku podlegała dużym zmianom. Tarnów w badanym okresie był klasyfikowany jako tak zwany garnizon średni (pomiędzy 1000 a 2500 żołnierzy). Daje się przy tym zauważyć, że na przełomie XIX i XX wieku w miastach, takich jak Przemyśl, Jarosław czy Stanisławów, garnizon powiększał się o wiele szybciej niż w Tarnowie² ${ }^{2}$.

1 M. Baczkowski, Pod czarno-żóttymi sztandarami. Galicja i jej mieszkańcy wobec austro-węgierskich struktur militarnych 1868-1914, Kraków 2003, s. 112.

2 Więcej informacji o strukturze garnizonów w Galicji oraz zmianach w ich liczebności i klasyfikacji zob. ibidem, s. 116-120. 


\section{SPECYFIKA TARNOWA NA PRZEŁOMIE XIXI XX WIEKU - MIASTO TYPOWE CZY WYJĄTKOWE?}

Tarnów na przełomie XIX i XX wieku był jednym z większych miast Galicji. Jego powierzchnia w 1857 roku wynosiła $17 \mathrm{~km}^{2}$. Została ona powiększona do I wojny światowej do $17,61 \mathrm{~km}^{23}$. W okresie autonomicznym ludność Tarnowa wzrosła z 21779 osób w 1869 roku do 36731 w 1910 roku$^{4}$. Na początku okresu autonomicznego 51\% mieszkańców stanowili Żydzi. W 1900 roku 40\% ludności było pochodzenia żydowskiego, a w przededniu wojny - 43\%. Około 56\% mieszkańców deklarowało się jako rzymscy katolicy, a 0,6\% stanowili grekokatolicy i protestanci ${ }^{5}$.

Od 1856 roku przez Tarnów przebiegała linia kolejowa łącząca Kraków z Dębicą. Później przedłużono ją do Lwowa. W 1876 roku oddano do użytku połączenie kolejowe z Węgrami, tak zwaną kolej leluchowską. W 1906 roku ukończono budowę drugiej linii kolejowej, łączącej Tarnów ze Szczucinem ${ }^{6}$. Tarnów stał się znaczącym węzłem kolejowym, co przyczyniło się od jego rozwoju. Pełnił także pewne funkcje administracyjne. Znajdowały się tutaj siedziba starostwa, sąd i siedziba biskupa diecezji rzymskokatolickiej'

Przed I wojną światową Tarnów był trzecim miastem w Galicji, jeżeli chodzi o nasycenie przemysłem (po Krakowie i Lwowie). Funkcjonowały tu głównie średnie i małe przedsiębiorstwa, ale reprezentowały większość gałęzi nowoczesnego przemysłu. W 1901 roku w Tarnowie działało: siedem przedsiębiorstw wytwarzających materiały budowlane oraz działających w branży budowlanej i kamieniarskiej, browar, trzy gorzelnie, dwie fabryki octu, trzy młyny zbożowe, przetwórnia cykorii, dwie fabryki konserw zupowych, dwa tartaki, fabryka tałesów i materiałów wełnianych, fabryka mydła, farb i lakierów, dwie fabryki świec, dwie apteki, fabryka gazu

3 J. Zdrada, Ziemia tarnowska w okresie autonomii galicyjskiej 1849-1918 [w:] Tarnów. Dzieje miasta i regionu, t. 2: Czasy rozbiorów i Drugiej Rzeczypospolitej, red. F. Kiryk, Z. Ruta, Tarnów 1983, s. 120, 122; A. Jelonek, Terytorium i ludność miasta Tarnowa [w:] Studia z geografii średnich miast w Polsce. Problematyka Tarnowa, Warszawa 1971, s. 36; Z. Simche, Tarnów i jego okolica, Tarnów 1993 (reprint wydania z 1930 r.), s. 57, 102; Stownik geograficzny Królestwa Polskiego i innych krajów słowiańskich, red. B. Chlebowski, t. 12, Warszawa 1892, s. 197.

4 J. Zdrada, Ziemia tarnowska..., s. 95.

5 Ibidem, s. 122-123.

6 M. Tyrowicz, B. Łopuszański, Ziemia tarnowska w okresie przedautonomicznym [w:] Tarnów. Dzieje miasta..., t. 2, s. 30; M. Tyrowicz, Tarnów i region tarnowski w dobie walk o wolność społeczna i narodowa [w:] Tarnów. Dzieje miasta..., t. 2, s. 53; J. Zdrada, Ziemia tarnowska ..., s. 119-120. O kolei w czasach austriackich zob. także: S. Szuro, Informator statystyczny do dziejów społeczno-gospodarczych Galicji. Koleje żelazne w Galicji w latach 1847-1914, Kraków 1997; W. Ko morow ski, Tarnowski węzet kolejowy. Historia i architektura, „Rocznik Tarnowski” 1991/1992, s. 125-132; idem, Tarnowski węzet kolejowy. Historia i architektura [w:] Tarnów. Wielki przewodnik, t. 19: Strusina, Tarnów 2009, s. 317-331.

7 J. Zdrada, Ziemia tarnowska..., s. 91; M. Tyrowicz, B. Łopuszański, op. cit., s. 43-47. 
świetlnego, koksu i smołowca, fabryka maszyn i pilników, odlewnia żelaza i metali, dwie firmy ślusarskie, garbarnia, pończoszarnia i huta szkła ${ }^{8}$.

Okres autonomiczny to czas przebudowy miasta i jego rozwoju. Wtedy powstawały nowe place, ulice oraz budynki użyteczności publicznej. Do najważniejszych osiągnięć cywilizacyjnych okresu autonomii, a zwłaszcza jej schyłkowego okresu, można zaliczyć budowę nowego wodociągu (1911 r.) i elektrowni (1910 r.) oraz uruchomienie linii tramwaju elektrycznego. Od 1865 roku w Tarnowie działała Ochotnicza Straż Pożarna?.

Przez cały okres zaborów w Tarnowie funkcjonowały szkoły podstawowe i średnie. Miasto było ośrodkiem edukacyjnym dla całego regionu. Rozbudowa sieci szkolnej nastąpiła dopiero w okresie autonomicznym ${ }^{10}$. Na przykład w 1882 roku w Tarnowie istniały dwie szkoły średnie - gimnazjum i męskie seminarium - oraz dziewięć szkół niższego szczebla i zawodowych. W sumie kształciło się w nich 3281 uczniów. W szkołach były przynajmniej 84 etaty nauczycielskie. W 1912 roku w Tarnowie działały już 23 szkoły, z czego cztery publiczne i jeden zespół prywatnych szkół średnich (liceum żeńskie oraz gimnazjum realne sióstr urszulanek) oraz 17 szkół innego typu. W poszczególnych placówkach uczyło się ponad 5100 uczniów. Liczba etatów nauczycielskich wzrosła do $260^{11}$. Ponadto działało seminarium duchowne ściśle związane $\mathrm{z}$ miejscową diecezją ${ }^{12}$.

Tarnów na przełomie XIX i XX wieku zanotował znaczny rozwój ekonomiczny i oświatowy. Miejscowość, dzięki licznym inwestycjom władz miejskich i prywatnych przedsiębiorców, zyskała oblicze europejskiego miasta pełnego nowoczesnych,

8 J. Zdrada, Ziemia tarnowska..., s. 96-107. O rozwoju gospodarczym miasta zob. także: J. Zdrada, Tarnów pod zaborem austriackim, cz. II (1848-1918); Rozwój gospodarczy Tarnowa [w:] Tarnów. Wielki przewodnik, t. 4, Tarnów 1997, s. 114-130. O poszczególnych zakładach przemysłowych zob. J. Bociek, B. Liszka, E. Jawień et al., Zakłady przemystowe w przedwojennym Tarnowie (I) [w:] Tarnów. Wielki przewodnik, t. 15: Grabówka, Tarnów 2007, s. 233-268; eidem, Zakłady przemystowe w przedwojennym Tarnowie (II) [w:] Tarnów. Wielki przewodnik, t. 18: Zabłocie, Tarnów 2008, s. 31-92; Księga adresowa przemysłu galicyjskiego, oprac. Krakowski Komitet I Zjazdu Przemysłowego, Kraków 1901.

9 J. Zdrada, Ziemia tarnowska..., s. 141-142; W. Skoraszewski, Wodociagi (I) [w:] Tarnów. Wielki przewodnik, t. 15: Grabówka, s. 7-10; S. Pikul, W. Olszówka, Tarnowskie Wodociagi (II) [w:] Tarnów. Wielki przewodnik, t. 19: Strusina, s. 41-50; C. Sterkowicz, Elektrownia. Zakład Energetyczny w Tarnowie [w:] Tarnów. Wielki przewodnik, t. 15: Grabówka, s. 185-194; S. Potępa, Tramwaje (25 września 1911-1939) [w:] Tarnów. Wielki przewodnik, t. 14: Grabówka, Tarnów 2006, s. 191-198; W. Knapik-Czosnek, Tarnowska Straż Pożarna [w:] Tarnów. Wielki przewodnik, t. 8: Zawale, Tarnów 2001, s. 13-49.

10 C. Majorek, W. Marmon, Oświata i kultura regionu tarnowskiego w okresie rozbiorów i niewoli. Rozwój szkolnictwa ludowego i pedagogicznego[w:] Tarnów. Dzieje miasta..., t. 2, s. 259-317; Z. Ruta, Oświata i kultura regionu tarnowskiego w okresie rozbiorów i niewoli. Szkolnictwo średnie i ogólnokształcace [w:] Tarnów. Dzieje miasta ..., t. 2, s. 318-359; S. Kmieć, J. Matula, Oświata i kultura regionu tarnowskiego w okresie rozbiorów i niewoli. Szkolnictwo zawodowe [w:] Tarnów. Dzieje miasta..., t. 2, s. 259-376.

11 ,Tarnowianin”, kalendarz na rok 1882, 1912.

12 Szerzej o seminarium: R. Banach, Powstanie i organizacja Seminarium Duchownego w Tarnowie, ,Rocznik Tarnowski” 1990, s. 29-42; idem, Seminarium Duchowne w Tarnowie w latach 1838 1859. W kręgu wydarzeń politycznych, „Rocznik Tarnowski” 1991/1992, s. 95-108. 
jak na ówczesne czasy, budynków użyteczności publicznej, posiadającego infrastrukturę sanitarną i transportową ${ }^{13}$ oraz będącego znacznym „zagłębiem” oświatowym na poziomie średnim i zawodowym. Oczywiście w większości rankingów Tarnów ustępował stołecznym miastom Galicji, czyli Lwowowi i Krakowowi, ale na tle tak zwanych miast ,znaczniejszych” prezentował się nad wyraz dobrze, stojąc na podobnym poziomie cywilizacyjnym co Stanisławów czy Przemyśl. Pod wieloma względami było to miasto typowe, gdy weźmie się pod uwagę podobnej wielkości ośrodki w całej Galicji. Za wyjątkowe można uznać bilanse budżetowe miasta, które przed I wojną światową korzystnie wyróżniały się na tle bilansów „znaczniejszych” miast prowincji.

\section{AUSTRO-WĘGIERSKI GARNIZON W TARNOWIE - ZARYS DZIEJÓW I SPECYFIKA}

Austriacki garnizon pojawił się w Tarnowie już w 1772 roku i pozostał w mieście aż do 1918 roku. W ciągu tych 146 lat zmieniały się wielkość załogi i jej skład, liczba instytucji wojskowych oraz stan infrastruktury wojskowej. Tarnów w początkowym okresie zaborów - jak się wydaje - nie wyróżniał się na tle innych miast Galicji podobnej wielkości; umieszczono tu siedzibę generała, kilka pododdziałów rezerwowych wojska, a także prawdopodobnie magazyn prowiantowy.

W kolejnych latach wzrastała liczebność załogi. Przykładowo pod koniec 1815 roku w Tarnowie stacjonowało 132 żołnierzy; w lipcu 1830 roku przebywało w nim przynajmniej 604 żołnierzy (142 kawalerzystów, 462 piechurów ${ }^{14}$ ); w grudniu 1840 roku w mieście kwaterowało 944 wojskowych, a w październiku 1846 roku - $1841^{15}$.

Od kongresu wiedeńskiego do 1846 roku Tarnów był największym centrum administracji wojskowej dla całej zachodniej części Galicji. W mieście znajdowało się dowództwo dywizji, jednej lub dwóch brygad, a także dowództwa pułków piechoty i kawalerii oraz ich oddziały liniowe, różnego typu instytucje i magazyny wojskowe. Po włączeniu Krakowa do monarchii austriackiej rola Tarnowa jako ośrodka administracji wojskowej zaczęła się zmniejszać. Równocześnie z utratą funkcji administracyjnej zaczęła jednak wzrastać liczebność garnizonu miasta, co

13 Jeszcze raz wspomnieć tutaj należy o tym, że Tarnów od 1911 r. był, oprócz Lwowa i Krakowa, jedynym miastem w Galicji posiadającym tramwaj.

14 Brak danych o liczebności jednego baonu.

15 Österreichisches Staatsarchiv (dalej: OeStA)/Kriegsarchiv (dalej: KA)/ Feldakten (dalej: FA)/ Altedeldakten (dalej: AFA)/karton (dalej: k.) 3821: Dislokations Tabellen. Galizien 1803-1853 (dalej: DTG 1803-1853): Dislokations Einteilung Pro Dezember 1815, Lemberg, 6 Jänner 1816; DTG 1803-1853: Detallierte Dislokations Tabelle (dalej: DDT) der k.k. Truppen in Galizien und in Bukowinen (ad P 1389), Lemberg, 16 Juli 1830; DTG 1803-1853: DDT der k.k. Truppen in Galizien und in Bukowinen für die October 1840 (ad G 5514/840), Lemberg, 1 Dezember 1840; OeStA/KA/FA/AFA/Alt.Fasz. 62a k. 1805 index 8 Reg. 8: Brigade Generalmajor Legedisch (Unruhen in Galizien), (einige Akten von 1845-1847) I-XIII. 
było związane z budową nowych pomieszczeń koszarowych i tendencją do koncentrowania wojska w większych skupiskach ${ }^{16}$. Ostatecznie w okresie autonomicznym garnizon Tarnowa ustabilizował się jako siedziba dowództwa brygady, komendy uzupełnień, miejsce zakwaterowania pułku piechoty, pułku kawalerii oraz batalionu piechoty Obrony Krajowej. Dodatkowo w mieście znajdował się jeden z większych w zachodniej części Galicji magazyn prowiantowy. W 1870 roku w Tarnowie stacjonowało 1805 żołnierzy, w 1885 roku - 1741, w 1890 roku - 1984, w 1900 roku 2137, a w $1910 \mathrm{roku}-1792^{17}$.

Warto zaznaczyć, że od lat 80. XIX wieku prawie cały garnizon składał się z miejscowych rekrutów. Żołnierze stanowili także dość duży odsetek mieszkańców Tarnowa. Przykładowo - według danych spisowych, różniących się nieco od podanych powyżej - w 1890 roku na 25657 mieszkańców przypadało 1918 żołnierzy, a w 1910 roku ludność Tarnowa wzrosła do 36731 ludzi, załoga wojskowa zmniejszyła się zaś do 1792 żołnierzy ${ }^{18}$. W 1890 roku żołnierze stanowili 7,48\% ludności miasta, w 1910 roku $-4,88 \%$. Dla porównania za Michałem Baczkowskim podaję dane dotyczące Wrocławia: w 1890 roku liczył on 335186 mieszkańców, a jego załoga wojskowa „zaledwie” 5285 żołnierzy, czyli stanowiła ona 1,58\% ludności miasta ${ }^{19}$.

\section{WZAJEMNE RELACJE MIĘDZY WOJSKIEM A LUDNOŚCIĄ CYWILNĄ}

Podane powyżej dane dotyczące liczebności załogi wojskowej Tarnowa i liczby mieszkańców miasta jednoznacznie dowodzą, że zbadanie relacji między tymi dwoma grupami jest ważne dla odtworzenia dziejów społecznych Tarnowa przełomu XIX i XX wieku. Opracowując zestawienie na temat tego, w jakie relacje wchodzili mieszkańcy i załoga wojskowa na przełomie XIX i XX wieku, posiłkowałem się zwłaszcza lokalną prasą, ale także oficjalnymi dokumentami tarnowskiej rady miejskiej, a częściowo również wspomnieniami tarnowian.

Życie codzienne garnizonu zamykało się w pewnych stałych ramach właściwych dla tak zwanego roku wojskowego oraz dnia wojskowego. Żołnierze powtarzali te same cykle roczne i dzienne. Dla mieszkańców największe znaczenie miał coroczny pobór do wojska, który obejmował właściwie każdego dorosłego mężczyznę w mieście i jego okolicy ${ }^{20}$.

16 W związku z rozwojem kolei łatwiej było przerzucić oddziały w określone miejsce niż rozmieszczać drobne formacje z jednego pułku w kilkunastu wsiach i miasteczkach, jak to często robiono $\mathrm{w}$ pierwszej połowie XIX w.

17 Brak danych dla lat 1874-1884. Militär Statistisches Jahrbuch, Wien 1870-1873, 1885-1907; S. Szuro, Informator statystyczny do dziejów społeczno-gospodarczych Galicji. Ludność wojskowa Austro-Wegier rekrutująca się i stacjonująca na terenie Galicji 1869-1913, Kraków-Warszawa 1990, t. 284; „Pogoń” 1911, nr 26.

18 „Pogoń” 1891, nr 8; 1911, nr 26.

19 M. Baczkowski, op. cit., s. 120.

20 Nawet zakładając, że część młodych mężczyzn unikała wcielenia do wojska i od razu była włączana do tzw. rezerwy uzupełniającej lub uznawana za niezdolnych do służby, to pamiętać należy o tym, 
Ponadto widocznym punktem styczności wojska i cywilów były regularne ćwiczenia wojskowe miejscowego garnizonu, które czasami utrudniały życie mieszkańcom ${ }^{21}$. Ćwiczenia odbywały się zazwyczaj w okresie letnim i wiązały się z powoływaniem na nie lokalnych rezerwistów. $Z$ organizacji roku i dnia wojskowego wynikały terminy nasilenia relacji z cywilami. Podczas przepustek żołnierze spędzali czas w tarnowskich szynkach i innych przybytkach, co automatycznie stwarzało liczne możliwości interakcji z cywilami. Podobnie było podczas poboru i ćwiczeń - wówczas w mieście skokowo wzrastała liczba wojskowych.

Żołnierze, jako jeden z filarów monarchii, często uczestniczyli w różnego typu oficjalnych uroczystościach państwowych. Korpus oficerski i żołnierze brali udział zwłaszcza w świętach dworu cesarskiego. Rokrocznie obchodzono urodziny cesarza. Nieco mniej wystawnie fetowano jego imieniny. Za to bardzo uroczyście świętowano rocznice objęcia tronu przez panującego. Okrągłe jubileusze, połączone z wręczaniem pamiątkowych odznaczeń, były hucznie obchodzone przez wojsko. Armia celebrowała także uroczystości związane z członkami rodziny cesarskiej, takie jak narodziny, śluby lub zgony najbliższych cesarza ${ }^{22}$.

Święta państwowe, niezależnie od wydarzenia lub osoby, jakich dotyczyły, zazwyczaj przebiegały według podobnego schematu, obejmującego mszę, przegląd wojsk i poczęstunek. Jak się wydaje, organizowanie różnego typu uroczystości miało dwojakie cele. $Z$ jednej strony miało umacniać lojalność wobec dynastii wśród żołnierzy przez pokazanie im splendoru domu panującego i przypomnienie, kto jest najwyższym wodzem. $Z$ drugiej strony przekonywało ludność cywilną, że armia stanowi jedną z podpór dynastii i państwa dzięki ciągłej obecności w przestrzeni publicznej. Udział wojska w uroczystościach państwowych dobitnie pokazywał, że dobrotliwy monarcha z Wiednia ma także liczne siły zbrojne, które będą broniły jego poddanych, ale także - w razie jakiegokolwiek wystąpienia przeciwko władzy - staną w obronie cesarza $^{23}$. Do oficjalnych wystąpień garnizonu zaliczały się uroczystości stricte wojskowe, takie jak poświęcenie sztandarów, rocznice powstania jednostek lub wielkich bitew.

Co charakterystyczne, na przełomie XIX i XX wieku uroczystości wojskowe nie znajdowały większego oddźwięku w społeczeństwie. Jak się wydaje, rocznice

że nieuregulowanie stosunku do służby wojskowej skutkowało problemami z wyjazdem z kraju w poszukiwaniu pracy, a także z wejściem w związek małżeński.

${ }^{21}$ Przykładowo w $1881 \mathrm{r}$. wg tarnowskiej prasy wojsko regularnie blokowało miejskie ulice podczas ćwiczeń i przemarszów. W 1889 r. redaktorzy wypomnieli, że wojsko maszeruje wczesnym rankiem na ćwiczenia przy dźwiękach trąbek i werbli, co budziło mieszkańców. Częstym problemem w Galicji, dotykającym także Tarnów, miał być zwyczaj chodzenia żołnierzy zwartymi grupami i spychania z trotuarów cywili, którzy nie chcieli ustąpić drogi wojsku. „Unia” 1886, nr 3; „Pogoń” 1881, nr 3, 9; 1889, nr 31; 1890, nr 5, 13, 20, 46; 1891, nr 15; 1897, nr 21; 1899, nr 24; 1908, nr 23.

22 Na przełomie XIX i XX w. wojsko uroczyście obchodziło urodziny cesarza (18 sierpnia), jego imieniny (4 października) oraz rocznicę objęcia tronu (2 grudnia).

${ }^{23}$ „Unia” 1882, nr 6; 1883, nr 18; 1885, nr 17; 1886, nr 17; „Pogoń” 1881, nr 9; 1882, nr 17; 1884, nr 17; 1888, nr 22; 1889, nr 34; 1890, nr 34; 1891, nr 34; 1892, nr 34; 1895, nr 33; 1896, nr 34; 1897, nr $34 ; 1898$, nr 34, 49; 1899, nr 34; 1900, nr 61, 68; 1901, nr 34; 1902, nr 33, 40; 1904, nr 34; 1906, nr 33; 1908, nr 48; 1913, nr 34 . 
utworzenia poszczególnych oddziałów były ważne głównie dla wysłużonych żołnierzy danego pułku. Rocznice potyczek czy bitew, w których wsławiły się poszczególne jednostki, również nie niosły dla społeczeństwa żadnego przekazu. Wiele jednostek wojskowych odwoływało się do tradycji bitew z okresu wojen napoleońskich lub nawet wcześniejszych. Brak oddźwięku nie powinien zatem dziwić, jeżeli weźmie się pod uwagę dość powszechną wówczas wiedzę, że w wielu bitwach, na przykład pod Lipskiem w 1813 roku, przeciw pułkom austriackim walczyły oddziały polskie w służbie francuskiej. Znamienne byłoby tu zwłaszcza przypomnienie casusu święta 57. Pułku Piechoty. Żołnierze tej jednostki podczas święta pułkowego wspominali potyczkę z Prusakami pod Oświęcimiem w 1866 roku. Gdy w 1901 roku pułk w Tarnowie hucznie obchodził tę rocznicę, prasa i mieszkańcy miasta wyrażali zdziwienie, dlaczego żołnierze maszerują przez miasto przy dźwiękach muzyki ${ }^{24}$.

Przy okazji opisu uroczystości wojskowych warto także wspomnieć o tak specyficznym widowisku, jakim były wyścigi konne organizowane przez wojskowych. Konkursy hippiczne przyciągały regularnie dużą grupę cywilnych obserwatorów. Wyścigami konnymi w kwietniu każdego roku kończyła się zimowa szkoła oficerska, tak zwana ekwitacyjna, 11. Brygady Kawalerii25. Wyścigi konne z udziałem oficerów miejscowego pułku ułanów odbywały się na podtarnowskich błoniach także w czerwcu i wrześniu, prawdopodobnie $\mathrm{w}$ związku z rozpoczęciem lub zakończeniem kolejnych ćwiczeń polowych. O zainteresowaniu Tarnowian tą formą aktywności wojskowej mogą świadczyć wydarzenia z 1888 roku. W prasie pojawiła się wówczas informacja, że wyścigi odbędą się 22 kwietnia, a w rzeczywistości odbyły się one dopiero tydzień później. 22 kwietnia liczni cywile pojawili się na wskazanym placu, a kiedy wojskowi nie przybyli, zebrani przeszli gremialnie do drugiego potencjalnego miejsca wyścigów. Opisana sytuacja $\mathrm{z}$ jednej strony świadczy o dużym zainteresowaniu wojskiem wśród ludności cywilnej, z drugiej jednak pokazuje całkowity brak komunikacji między tymi dwoma grupami. Oficerowie prawdopodobnie nie czytali miejscowej prasy lub czytali, ale nie uznali za słuszne sprostować błędnej informacji ${ }^{26}$.

Kolejną kategorią oficjalnych wystąpień, w których brali udział żołnierze, były rożnego typu uroczystości religijne. Swoiste współistnienie tronu i ołtarza w monarchii austro-węgierskiej w przypadku Tarnowa przejawiało się udziałem oddziałów garnizonu jako kompanii honorowych w mszach i procesjach. Żołnierze widoczni i słyszalni byli zwłaszcza podczas procesji z okazji Bożego Ciała. Nie sądzę jednak, żeby organizowanie „strzelanego odpustu” i udział wojska w tym wydarzeniu były świadomymi działaniami propagandowymi, wykreowanymi przez decydentów tarnowskiego garnizonu w celu „ocieplenia” wizerunku wojska w społeczeństwie, które mogłoby dzięki temu traktować armię jako „swoją”. Bardziej prawdopodobne

24 „Pogoń” 1889, nr 34; 1890, nr 37; 1901, nr 25, 28, 29.

2515 kwietnia 1882 r. w jednym z wyścigów konnych zorganizowanych na zakończenie nauki w szkole ekwitacyjnej zwyciężył porucznik 1. Pułku Ułanów Tadeusz Kossak, syn malarza Juliusza. Redaktorzy miejscowej prasy skomentowali: „Ojciec dzielnie konie maluje, syn znakomicie na koniu harcuje".

26 „Unia” 1886, nr 9; 1888, nr 9; „Pogoń” 1882, nr 9; 1885, nr 9; 1886, nr 9, 12; 1887, nr 9, 20; 1888, nr 9, 10; 1889, nr 16;1890, nr 36;1891, nr 17, 36. 
wydaje się twierdzenie, że wojsko uczestniczyło w uroczystościach religijnych, wypełniając habsburską ideę państwowo-dynastyczną, w którą wpisywały się związki $\mathrm{z}$ religią rzymskokatolicką ${ }^{27}$.

Ciekawym przykładem koegzystencji ludności cywilnej i wojska był udział tego ostatniego w szeroko pojętym życiu towarzyskim i kulturalnym Tarnowa. Wojskowi uczestniczyli w balach organizowanych przez tarnowskich cywili lub też sami takie bale organizowali. To, co wyróżniało Tarnów przełomu XIX i XX wieku, to fakt istnienia w mieście wspólnego Towarzystwa Kasynowego, skupiającego zarówno wojskowych, jak i cywili. Zwłaszcza oficerowie byli cenionymi uczestnikami wszelkiego typu balów i rautów z powodu posiadania umiejętności tanecznych wyniesionych ze szkół wojskowych. Pamiętać należy także o tym, że część oficerów, zwłaszcza kawalerii, należała do środowiska szlachecko-ziemiańskiego, często spokrewnionego z tarnowską elitą urzędniczą i finansową ${ }^{28}$.

Jak się wydaje, najbardziej widoczny (czy też słyszalny) wkład w życie kulturalne Tarnowa przełomu XIX i XX wieku miała orkiestra wojskowa. W prasie tarnowskiej z lat 1894-1914 znajduje się ponad 150 wzmianek o jej występach ${ }^{29}$. Oczywiste jest, że orkiestra wojskowa występowała podczas uroczystości domu cesarskiego. Bardziej interesująca może się jednak wydać współpraca orkiestry austro-węgierskiego pułku piechoty z tarnowskim „Sokołem” ${ }^{30}$ czy też koncerty, z których dochód przeznaczony był na fundusz budowy w Tarnowie pomnika Adama Mickiewicza (maj 1898 r., październik 1900 r.). Ciekawa wydaje się również wzmianka o występie orkiestry 57. Pułku Piechoty na rzecz gimnazjum polskiego w Cieszynie (czerwiec 1895 r.) ${ }^{31}$.

Do wzmocnienia wzajemnych relacji między wojskiem a cywilami przyczyniało się założone w Tarnowie w 1902 roku Towarzystwo c.k. Weteranów Wojskowych. Stowarzyszenie w 1902 roku skupiało 52 członków, byłych żołnierzy austro-węgierskich. W 1909 roku do jego władz wybrano aż 22 osoby, co może dawać jakieś pojęcie o liczbie członków. Ostatnia wzmianka prasowa o towarzystwie pochodzi z 1912 roku, co świadczy o tym, że organizacja zawiesiła lub ograniczyła działalność. Ciekawą kwestią pozostaje to, że na początku XX wieku w mieście z dość silnym

27 Archiwum Narodowe w Krakowie, Oddział w Tarnowie (dalej: ANKrOT)/Akta Miasta Tarnowa (dalej: AMT)/sygn. MT-7/a, Protokół posiedzenia rady miejskiej z 23 maja 1898; „Pogoń” 1886, nr 11; 1888, nr 8; 1898, nr 17, 22; 1903, nr 31; 1906, nr 24.

28 J. Szymczak-Hoff, Życie towarzyskie i kulturalne Rzeszowa w dobie autonomii Galicji, Rzeszów 1993, s. 21-26, 109-110. „Pogoń” 1882, nr 5; 1890, nr 9, 1894, nr 2; 1897, nr 6; 1902, nr 5; 1913, nr 4; 1914, nr 7, 20; „Unia” 1886, nr 1; 1888, nr 3.

29 Brak orkiestry wojskowej w Tarnowie był częstym argumentem podczas dyskusji na temat obecności wojska w mieście. Jak się wydaje, orkiestra wojskowa 57. Pułku Piechoty stanowiła jedną z największych atrakcji dla mieszkańców. Jej wspomnienie z czasów swego dzieciństwa przytacza w pamiętnikach Roman Brandstaetter. Ostatecznie orkiestra 57. Pułku Piechoty została sprowadzona do Tarnowa w 1894 r. R. Brandstaetter, Przypadki mojego życia, Poznań 1988, s. 22-23.

30 Festyny w sierpniu i wrześniu 1895 r., koncert w grudniu tego samego roku, choinka w styczniu i koncert spacerowy w listopadzie 1896 r., koncert w sierpniu 1897 r., festyn w czerwcu 1902 r., tombola w marcu 1904 r., kiermasz i reunion w październiku 1906 r., festyn we wrześniu 1907 r. oraz w czerwcu 1909 i 1913 r.

31 Listę wystąpień orkiestry wojskowej w latach 1894-1914 opublikowałem w książce: Cesarskie dzieci z Tarnowa. 57. galicyjski pułk piechoty w latach 1894-1918, Kraków 2011, s. 90-95. 
żywiołem polskim funkcjonowała organizacja, której członkowie nawet w życiu cywilnym nawiązywali do wspólnej identyfikacji wokół służby wojskowej. Wyjaśnienie tej sytuacji można odnaleźć w nekrologach zmarłych członków towarzystwa. W latach 1902-1912 w prasie tarnowskiej pojawiły się cztery takie wzmianki. Zmarli reprezentowali różne zawody i odgrywali różne role społeczne. Byli to odpowiednio: podurzędnik pocztowy, komendant miejskiej straży pożarnej, majster studniarski oraz kancelista katastralny. Trzy z tych stanowisk to niższe funkcje urzędnicze, de facto zarezerwowane dla wysłużonych podoficerów. Być może właśnie to zapewnienie przez państwo dogodnego startu w życiu cywilnym powodowało utrzymywanie się identyfikacji z armią także po zakończeniu służby ${ }^{32}$.

Na funkcjonowanie wojska w Tarnowie i jego relacje z cywilami miały też wpływ przestępstwa i wykroczenia popełniane przez żołnierzy oraz na żołnierzach. Protokoły kar tarnowskiego sądu garnizonowego od lat 50. XIX wieku aż do 1914 roku rokrocznie zawierały nazwiska od 45 do ponad 200 żołnierzy miejscowego garnizonu, skazanych przez sąd wojskowy za różnego typu przestępstwa. Trudno jednak skorelować liczebność lub skład etniczny garnizonu z wahaniami liczby przestępstw żołnierskich ${ }^{33}$. Czasami to także wojskowi padali ofiarami przestępstw, zwłaszcza oficerowie stawali się ofiarami kradzieży, a szeregowcy - pobić3 ${ }^{34}$. Część żołnierzy garnizonu Tarnowa nie wytrzymywała trudów służby i popełniała samobójstwa. Jak się wydaje, liczba samobójstw nie przekraczała średniej armijnej, nie zmienia to jednak faktu, że większość samobójstw była spowodowana przyczynami związanymi

32 „Pogoń” 1902, nr 7; 1903, nr 7, 22; 1904, nr 12, 24; 1905, nr 3; 1906, nr 14, 21, 32; 1907, nr 3, 27, 28; 1908, nr 5, 25; 1909, nr 4, 19; 1910, nr 17; 1911, nr 16, 44; 1912, nr 6, 17.

33 W 1895 r. przed sądem wojskowym w Tarnowie stanęło 100 żołnierzy, głównie z 57. Pułku Piechoty, 2. Pułku Ułanów i 13. Batalionu Strzelców Polowych. Wykroczenia prezentowały się następująco: 30 spraw dotyczyło kradzieży, 17 - wystąpienia przeciwko bezpieczeństwu własności, tyle samo - wystąpienia przeciw bezpieczeństwu ciała, 12 - dezercji, 11 - zaniedbania na warcie, 8 - samowolnego oddalenia się ze służby. W 1910 r. przed sądem stanęło 76 żołnierzy, w tym aż 46 z 57. Pułku Piechoty; 24 sprawy dotyczyły kradzieży, 11 - wystąpienia przeciwko dyscyplinie i porządkowi, 10 - samowolnego oddalenia się ze służby, po 9 - dezercji i niesubordynacji, 8 - ciężkiego uszkodzenia ciała. Archiwum Główne Akt Dawnych (dalej: AGAD)/Zespół: 416 Sądy wojskowe I korpusu/sygn. 1182, K.u.K. Garnisons-Gericht in Tarnów, Arestanten Protocoll 1895; M. Baczkowski, op. cit., s. 346. W prasie tarnowskiej informacji o przestępstwach i wykroczeniach jest zdecydowanie mniej, niż wynikałoby to z analizy protokołów sądowych. W latach 1894-1914 w prasie pojawiły się cztery wzmianki o kradzieżach i włamaniach z udziałem żołnierzy, jedna wzmianka o gwałcie, dwie informacje o zabójstwie (z czego jedna okazała się plotką). Dziesięciokrotnie w tym okresie pojawiła się informacja o użyciu broni w porachunkach między żołnierzami a cywilami. Pięciokrotnie żołnierze byli wzmiankowani jako uczestnicy lub prowodyrzy bójek. „Pogoń” 1895, nr 10-11, 16; 1896, nr 22; 1897, nr 25, 30, 39; 1899, nr 27; 1901, nr 39, 48; 1903, nr 16, 35; 1904, nr 21, 48; 1906, nr 24; 1907, nr 47; 1908, nr 10, 43; 1909, nr 20, 41; 1913, nr 10, 18; „Gazeta Tarnowska” 1908, nr 4. Oprócz przestępstw często dochodziło do awantur między cywilami a wojskowymi lub narzekań na zachowanie żołnierzy wobec cywilów. Przykładowo w 1896 r. podczas świętowania ukończenia zimowej szkoły kawaleryjskiej jej uczestnicy, oficerowie okolicznych pułków kawalerii, urządzili huczną, całonocną imprezę w hotelu, połączoną z puszczaniem petard i wyrzucaniem przez okno elementów wyposażenia hotelu. W marcu 1909 r. żołnierze zmusili z kolei do opuszczenia jednego z tarnowskich lokali cywilów, którzy nie chcieli śpiewać z nimi pieśni wojskowych. „Pogoń” 1896, nr 18, 20; 1897, nr 52; 1902, nr 45; 1908, nr 17, 20; 1909, nr 8, 11.

34 „Pogoń” 1887, nr 18; 1890, nr 6, 42, 43; 1892, nr 25; 1910, nr 4; 1912, nr 2, 6; 1913, nr 36. 
z pełnieniem służby, takimi jak spodziewana kara, pominięcie w awansie lub szykany ze strony przełożonych ${ }^{35}$.

Żołnierze nie tylko występowali przeciwko prawu i porządkowi społecznemu, ale również tego porządku bronili. Tarnowska prasa z przełomu XIX i XX wieku kilkakrotnie podawała informacje o ratowaniu życia lub zdrowia cywilów atakowanych przez silniejszych lub liczniejszych przeciwników. Wojsko także wspomagało policję miejską lub straż więzienną w sytuacjach, kiedy siły tych formacji okazały się niewystarczające ${ }^{36}$. Żołnierze z Tarnowa byli też czasami wykorzystywani do pacyfikowania różnego typu wystąpień na tle narodowościowym lub społecznym poza terenem miasta ${ }^{37}$. Charakterystyczny i znamienny jest zwłaszcza przykład z 1898 roku - żołnierze z garnizonu tarnowskiego, którzy na terenie miasta często manifestowali swój antysemityzm ${ }^{38}$, równocześnie bez większych problemów pacyfikowali takie nastroje w okolicach Jasła i Nowego Sącza ${ }^{39}$.

Armia działała na rzecz poprawy bezpieczeństwa mieszkańców, przejmując obowiązki straży pożarnej i walcząc z zagrożeniem pożarowym często pojawiającym się w mieście. Prawdopodobnie, przynajmniej przez część badanego okresu, wojskowa straż pożarna była lepiej wyposażona i liczniejsza niż analogiczne formacje miejskie.

35 Prasa tarnowska z lat 1894-1914 przytacza osiem przypadków samobójstw żołnierzy. W większości byli to żołnierze 57. Pułku Piechoty. „Pogoń” 1897, nr 29; 1901, nr 4; 1902, nr 37; 1903, nr 16; 1911, nr 30; 1913, nr 13; „Gazeta Tarnowska” 1909, nr 12.

36 Przykładowo w $1906 \mathrm{r}$. do stłumienia buntu w tarnowskim więzieniu skierowano dwie kompanie wojska, a samo ich dyslokowanie w pobliże więzienia przyczyniło się do zakończenia rozruchów. W roli strażników porządku publicznego żołnierze wystąpili także w sierpniu 1909 r., kiedy jeden z tarnowskich fiakrów zaatakował i ciężko zranił usiłującego wylegitymować go tarnowskiego policjanta. Poszkodowanego przed dalszymi atakami rozwścieczonego woźnicy uratowała interwencja kilku oficerów, którzy widząc, co się dzieje - nadbiegli i obezwładnili napastnika. „Pogoń” 1906, nr 23; 1909, nr 35.

37 Przykładowo w kwietniu 1890 r. dwa bataliony strzelców polowych z Tarnowa zostały skierowane poza miasto w celu stłumienia zamieszek robotniczych w okręgu przemysłowym Morawska Ostrawa. W 1905 r. żołnierze z Tarnowa zostali skierowani na Węgry w celu zabezpieczenia wyborów. „Pogoń” 1890, nr 16, 19; 1905, nr 5; W. Sokol, Geschichte des $k$. und k. Feldjäger-Bataillons Nr. 13., Bochnia 1899 , s. $300-303$.

38 Prasa tarnowska w 1897 r. dwukrotnie informowała o atakach żołnierzy na Żydów w Tarnowie i jego okolicy. Do jednego z takich ataków miało dojść w lipcu tego roku na tarnowskim przedmieściu Grabówce, przy czym prasa podała, że konfrontacja między poszkodowanymi a żołnierzami nie wykazała winnych. We wrześniu 1897 r. jacyś żołnierze mieli zaatakować Żydów na drodze między Tarnowem a Pilznem. Słynna stała się także sprawa z września 1905 r., kiedy to trzech oficerów 2. Pułku Ułanów: rotmistrz Alfred Słonecki, rotmistrz Breza (prawdopodobnie chodzi o podporucznika Stanisława hrabiego Brezę, w prasie z błędnym stopniem wojskowym) i porucznik Ferdynand, hrabia Montecuccoli-Pollnago, wywołali zamieszki antyżydowskie w Tarnowie. Pod wpływem alkoholu rzeczeni oficerowie zaczęli demolować tarnowskie sklepy, szczególnie te należące do jednego z żydowskich kupców. Powstrzymali ich inni oficerowie z 2. Pułku Ułanów. Następnego dnia żołnierze i podoficerowie 2. Pułku Ułanów (na wezwanie rotmistrza Słoneckiego: ,jeżeli mnie lubicie, to mnie pomścijcie”) zaczęli jednak demolować dzielnicę żydowską. Żandarmeria schwytała tylko jednego z napastników, a zamieszki odbiły się echem nawet w Radzie Państwa. Charakterystyczne w tym przypadku i - jak się wydaje - dość poważnie rzutujące na relacje między wojskiem a cywilami było także to, że mimo ewidentnych dowodów winy sąd wojskowy w Tarnowie nie ukarał żadnego ułana: AGAD/Zespół: 416 Sądy wojskowe I korpusu/sygn. 1174: K. und k. Garnisons-Gericht in Tarnow, Strafprotokol 1905; „Pogoń” 1897, nr 30, 39; 1905, nr 40; M. Baczkowski, op. cit., s. 351.

39 „Pogoń” 1898, nr 26, 36. 
Nie bez znaczenia okazała się możliwość wykorzystania do gaszenia pożarów zwartych pododdziałów wojska posiadających hierarchię służbową i przyzwyczajonych do wykonywania rozkazów, a przez to skuteczniejszych w walce z pożogą ${ }^{40}$.

Do wzajemnych kontaktów należały także relacje towarzyskie i osobiste, często kończące się małżeństwami łączącymi świat wojskowy i cywilny ${ }^{41}$.

W ciekawy sposób wzajemne relacje między wojskiem a ludnością opisuje w swoich wspomnieniach Walerian Zaklika. Mieszkał on w Tarnowie na przełomie XIX i XX wieku i jako syn miejscowego urzędnika sądowego otarł się także o życie garnizonu. Jego rodzina należała do lokalnej elity i utrzymywała dość dobre relacje z oficerami, zwłaszcza 2. Pułku Ułanów. Zaklika opisywał bale z udziałem oficerów, wyścigi konne i gry karciane, do udziału w których zapraszano zarówno oficerów, jak i cywilów ${ }^{42}$.

Innym aspektem relacji między wojskiem a ludnością cywilną była konieczność zapewnienia przez miasto odpowiednich pomieszczeń mieszkalnych dla szeregowych i oficerów. Na przełomie XIX i XX wieku żołnierze w większości mieszkali już w przeznaczonych do tego celu budynkach koszarowych, ale sporadycznie pojawiała się także konieczność wynajmu dodatkowych pomieszczeń. Oczywiście zakwaterowanie w koszarach dotyczyło głównie żołnierzy i podoficerów. Większość oficerów, zwłaszcza tych wyższych rangą i posiadających rodziny, wynajmowało prywatne mieszkania na własny koszt. Dodatkowo wynajmowano pomieszczenia dla szeregowych i oficerów jednostek przechodzących przez Tarnów oraz uczestniczących w ćwiczeniach w mieście i okolicy. Kwaterunek wojska był dochodowym interesem, skoro do 1905 roku w mieście funkcjonowały tak zwane koszary książęce, wynajmowane na potrzeby wojska od księcia Sanguszki. Roczny koszt wynajmu tych obiektów w latach 1900-1902 wynosił 2400 koron rocznie ${ }^{43}$. Oprócz wspomnianych koszar, zwłaszcza we wcześniejszym okresie, istniały jeszcze inne lokale przygotowywane pod wynajem na potrzeby wojska przez wielu mniejszych przedsiębiorców i właścicieli nieruchomości. Pewne dane na temat warunków zakwaterowania oraz podejścia przedsiębiorców do kwaterunku daje opis sytuacji z 1884 roku, zamiesz-

40 W tarnowskiej prasie $\mathrm{z}$ lat 1894-1914 znajduje się 12 wzmianek o działaniach wojskowej straży pożarnej lub tarnowskiego garnizonu na rzecz ochrony przeciwpożarowej miasta. „Pogoń” 1896, nr 42-44, 47; 1898, nr 2; 1901, nr 51; 1902, nr 17; 1904, nr 25, 32, 34; 1905, nr 20; 1907, nr 20.

41 W latach 1894-1914 na łamach miejscowej prasy pojawiło się 25 informacji o wstapieniu w związki małżeńskie oficerów i żołnierzy miejscowego garnizonu lub w jakikolwiek inny sposób związanych z Tarnowem. Dziesięć wzmianek dotyczyło oficerów służby czynnej jednostek miejscowego garnizonu, dwie - oficerów rezerwy, a jedna - byłego oficera. W pięciu przypadkach chodziło o śluby córek członków garnizonu. Obserwując tak relatywnie małą liczbę wzmianek o żołnierzach wstępujących w związki małżeńskie, należy pamiętać o zasadach panujących w armii austro-węgierskiej (dopuszczały one do służby jedynie określony procent żonatych oficerów) oraz o dodatkowych obostrzeniach finansowych dla kandydatek na żony oficerów. „Pogoń” 1894, nr 3, 44; 1895, nr 43; 1897, nr 18; 1899, nr 7, 38, 46,$48 ; 1900$, nr 48, 67, 72, 73; 1902, nr 5, 47; 1903, nr 19, 26; 1906, nr 21; 1905, nr 28; 1907, nr 18, 33; 1908, nr 35; 1910, nr 3, 15, 43; 1913, nr 21; M. Baczkowski, op. cit., s. 141.

42 Biblioteka Zakładu Narodowego im. Ossolińskich, Dział Rękopisów, sygn.15653/II Walerian Zaklika, Wspomnienia z lat 1886-1958.

43 ANKrOT/AMT/MT-7/c, Protokół posiedzenia rady miejskiej z 11 października 1900 r.; J. Leniek, F. Herzig, F. Leśniak, Dzieje miasta Tarnowa, Tarnów 1911, s. 259. 
czony w miejscowej prasie. Mianowicie w sierpniu tego roku na podwórzu jednej z kamienic przy ulicy Krakowskiej jej właściciel zbudował drewnianą szopę jako mieszkanie dla stróża oraz, w razie potrzeby, także dla kwaterunku żołnierzy. Redakcja zwracała uwagę, że jakość materiałów i wykonanie obiektu powodują znaczne zagrożenie pożarowe. W związku z powyższym zwracano uwagę, że kwaterunek żołnierzy w tym miejscu nie jest dobrym pomysłem. Informacja prasowa wskazuje na kilka aspektów kwaterunku żołnierzy w mieście. $\mathrm{Z}$ powodu braku odpowiednich koszar obowiązek zapewnienia kwater dla wojska spadał na miasto, które szukało wsparcia wśród właścicieli posesji. To, że prywatny właściciel sam wybudował obiekt z przeznaczeniem na możliwy kwaterunek wojska, oznacza, że istniało takie zapotrzebowanie, a jednocześnie był to dochodowy interes. Poruszona kwestia kiepskich materiałów i wykonania wskazywała na występujące patologie w tej dziedzinie oraz brak długofalowej polityki władz miejskich i wojskowych w zakresie kwaterunku żołnierzy w Tarnowie. Zwrócenie uwagi na zagrożenie pożarowe związane z kwaterunkiem wojska wskazuje na swoisty brak zaufania do wojskowych jako potencjalnych sprawców zagrożenia także dla innych mieszkańców. W końcu to, że inserat w ogóle się pojawił, sugeruje, że prasa, a więc i czytelnicy byli zainteresowani kwestią kwaterunku, możliwe że głównie w kontekście zagrożenia, jakie stwarzało wojsko ${ }^{44}$.

Wynajem dla wyższych oficerów (w którym partycypowało miasto), potrzebujących odpowiednio lepszych kwater, o większej powierzchni, zazwyczaj całych, wielopokojowych mieszkań, dotyczył na przełomie XIX i XX wieku około 10 oficerów. Byli to: generał major dowodzący lokalną brygadą, dwóch pułkowników dowodzących tarnowskim pułkiem piechoty i pułkiem kawalerii oraz pięciu lub sześciu oficerów sztabowych niższej rangi (podpułkownik, major) - dowódca batalionu zapasowego/okręgu uzupełnień pułku piechoty, dowódca batalionu Obrony Krajowej, dowódca dywizjonu ułanów, trzech lub czterech dowódców batalionów pułku piechoty. Do tej liczby należałoby dodać także wojskowych lekarzy w rangach oficerów sztabowych, przy czym etaty pułków piechoty i kawalerii wskazywałyby, że była to dość rzadka sytuacja (etatowo najstarszy rangą lekarz w jednostkach liniowych to lekarz pułkowy, czyli odpowiednik kapitana). Pamiętając o funkcjonowaniu w Tarnowie sądu wojskowego, musimy założyć, że wynajem kwater dla wyższych oficerów dotyczył także sztabowców-audytorów. Koszt wynajmu takich mieszkań był dość wysoki i w roku 1887 miał kosztować miasto 5508 złotych reńskich ${ }^{45}$. Dość dobrze koreluje to z danymi szczegółowymi dotyczącymi poszczególnych oficerów, dla których koszt wynajmu mieszkania oscylował w granicach 500 złotych reńskich rocznie ${ }^{46}$.

44 „Pogoń” 1884, nr 18.

45 „Pogoń” 1886, nr 13.

46 Przykładowo na posiedzeniu z 10 sierpnia 1893 r. tarnowska rada miejska zatwierdziła wynajem mieszkania dla majora Czajkowskiego z 57. Pułku Piechoty. Mieszkanie znajdowało się na piętrze budynku propinacji i zostało udostępnione na okres od 1 IX 1893 r. do 30 VI 1894 r. Czynsz kwartalny miał wynieść 112 złotych reńskich i 50 centymów (a zatem koszt roczny to 450 złotych reńskich). 8 XI 1894 r. tarnowska rada miejska postanowiła zaś wynająć mieszkanie dla podpułkownika 57. Pułku Piechoty 
Wynajem pomieszczeń dla oficerów niższych stopni, w którym już nie partycypowało miasto, prawdopodobnie zapewniał mniejszy dochód właścicielom nieruchomości, ale też mógł być spory i oscylował zapewne wokół 100-300 złotych reńskich rocznie.

Kwaterunek wojska stanowił jeden $\mathrm{z}$ aspektów wzajemnych relacji gospodarczych między wojskiem a cywilami. Zaliczały się do nich również dostawy dla wojska i sposoby spędzania przez żołnierzy wolnego czasu, zazwyczaj polegające na odwiedzaniu lokalnych „rozrywek”, takich jak szynki ${ }^{47}$ czy też na korzystaniu z usług miejscowych kobiet lekkich obyczajów. Trudno niestety ocenić, jak dużo pieniędzy zostawiali w miejscowych przybytkach żołnierze na przepustkach, a także jaki był rzeczywisty udział wojska w gospodarce miejskiej.

Michał Baczkowski ocenia, że jeżeli chodzi o wynajem pomieszczeń dla wojska, Tarnów jako jedyne miasto w Galicji miał dodatni bilans finansowy w relacjach z wojskiem ${ }^{48}$.

\section{PODSUMOWANIE}

Całokształt codziennych relacji między wojskiem a ludnością cywilną w Tarnowie stanowił bardzo skomplikowaną mozaikę. Punkty styczności między światami cywilnym i wojskowym były bardzo liczne, zarówno w sferze oficjalnej, jak i prywatnej. Relacje między wojskiem a cywilami miały wydźwięk pozytywny i negatywny. Wojskowi pomagali i bronili ludności cywilnej w sytuacjach niebezpieczeństwa wewnętrznego i zewnętrznego, ale też pozostawali ciągłym zagrożeniem, zwłaszcza w przypadku tłumienia różnego rodzaju wystąpień antysystemowych. Ponadto ich zwyczaje, zwłaszcza te związane ze spędzaniem wolnego czasu, były dla cywilów niezrozumiałe lub wręcz sprzeczne z zasadami współżycia społecznego. Sądzę jednak, że wojsko stanowiło ważny i widoczny element społeczności Tarnowa oraz, przynajmniej od drugiej połowy XIX wieku, nadawało ton wielu formom aktywności społecznej w mieście. To właśnie żołnierze - na co dzień przebywający w Tarnowie, często pochodzący z samego miasta i jego najbliższej okolicy - przyczyniali się, mimo problemów, które powodowali, do uznania armii austriackiej (austro-węgierskiej) za „swoją”. Pewną formą wzajemnych relacji między wojskiem a cywilami były także związki „gospodarcze”, takie jak wynajem pomieszczeń koszarowych i mieszkalnych, dostawy dla wojska czy też różnorodne usługi, czasami zahaczające o patologie, na przykład pijaństwo czy prostytucję.

\footnotetext{
w budynku Korduli Veith z czynszem rocznym w wysokości 500 złotych reńskich. ANKrOT/AMT/MT6, Protokół posiedzenia rady miejskiej z 10 sierpnia 1893 r.; „Pogoń” 1894, nr 45; ANKrOT/AMT/MT-6, Protokół posiedzenia rady miejskiej z 8 listopada $1894 \mathrm{r}$.

47 Lub też, w przypadku oficerów, kawiarni i restauracji.

48 O roli gospodarczej wojska w Galicji zob. w: M. Baczkowski, op. cit., s. 297-321.
} 
Po 1918 roku armia austro-węgierska zasiliła Wojsko Polskie zarówno licznymi rzeszami doskonale wyszkolonych żołnierzy, oficerów i urzędników wojskowych, jak i rozbudowaną infrastrukturą. Już wtedy jednak zaczęto wypierać z oficjalnego dyskursu żołnierzy armii zaborczych, ich dzieje i wpływ na rozwój miejscowości, w których stacjonowali.

Sadzę, że odtworzenie dziejów garnizonu Tarnów, a zwłaszcza udziału wojska w życiu cywilnej ludności, jest dobrym punktem wyjścia do dalszych badań. Istniejące, szczątkowe informacje dla innych ośrodków garnizonowych z terenu Galicji dają dobrą podstawę do twierdzenia, że wiele typów relacji (a może nawet wszystkie) między cywilami i wojskiem wspomnianych w niniejszym artykule istniało także w tych ośrodkach.

\section{BIBLIOGRAFIA}

\section{Źródła archiwalne}

Archiwum Główne Akt Dawnych w Warszawie

Zespół: 416 Sądy wojskowe I korpusu:

sygn. 1182, K.u.K. Garnisons-Gericht in Tarnów, Arestanten protokol 1895.

Archiwum Narodowe w Krakowie, Oddział w Tarnowie

Zespół: Akta Miasta Tarnowa:

MT-6, Protokoły Rady Miejskiej od 1 lipca 1890 do końca 1897 roku.

MT-7, Protokoły Rady Miejskiej (a) 1898.

MT-7, Protokoły Rady Miejskiej (c) 1900.

Biblioteka Zakładu Narodowego im. Ossolińskich we Wrocławiu

Dział Rękopisów:

sygn. 15653/II Walerian Zaklika, Wspomnienia z lat 1886-1958.

Österreichisches Staatsarchiv w Wiedniu

Oddział: Kriegsarchiv

Zespół: Altefeldakten:

k. 3821: Dislokations Tabellen. Galizien 1803-1853.

Alt.Fasz. 62a k.1805 index 8 Reg. 8: Brigade Generalmajor Legedisch (Unruhen in Galizien), (einige Akten von 1845-1847) I-XIII.

\section{Źródła drukowane}

Brandstaetter R., Przypadki mojego życia, Poznań 1988. 
Księga adresowa przemystu galicyjskiego, oprac. Krakowski Komitet I Zjazdu Przemysłowego, Kraków 1901.

Militär Statistisches Jahrbuch, Wien 1870-1873, 1885-1907.

Słownik geograficzny Królestwa Polskiego i innych krajów słowiańskich, t. 12, red. B. Chlebowski, Warszawa 1892.

„, Tarnowianin”, kalendarz na rok 1882, 1912.

\section{Prasa}

„Gazeta Tarnowska” 1908-1909.

„Pogoń” (Tarnów) 1881-1914.

„Unia” (Tarnów) 1882-1888.

\section{Opracowania}

Baczkowski M., Pod czarno-żóttymi sztandarami. Galicja i jej mieszkańcy wobec austro-węgierskich struktur militarnych 1868-1914, Kraków 2003.

Banach R., Powstanie i organizacja Seminarium Duchownego w Tarnowie, „Rocznik Tarnowski" 1990, s. 29-42.

Banach R., Seminarium Duchowne w Tarnowie w latach 1838-1859. W kregu wydarzeń politycznych, „Rocznik Tarnowski” 1991/1992, s. 95-108.

Bociek J., Liszka B., Jawień E. et al., Zakłady przemysłowe w przedwojennym Tarnowie (I) [w:] Tarnów. Wielki przewodnik, t. 15: Grabówka, Tarnów 2007, s. 233-268.

Bociek J., Liszka B., Jawień E. et al., Zakłady przemysłowe w przedwojennym Tarnowie (II) [w:] Tarnów. Wielki przewodnik, t. 18: Zabłocie, Tarnów 2008, s. 31-92.

Jelonek A., Terytorium i ludność miasta Tarnowa [w:] Studia z geografii średnich miast w Polsce. Problematyka Tarnowa, Warszawa 1971.

Kmieć S., Matula J., Oświata i kultura regionu tarnowskiego w okresie rozbiorów i niewoli. Szkolnictwo zawodowe [w:] Tarnów. Dzieje miasta i regionu, t. 2: Czasy rozbiorów i Drugiej Rzeczypospolitej, red. F. Kiryk, Z. Ruta, Tarnów 1983.

Knapik-Czosnek W., Tarnowska Straż Pożarna [w:] Tarnów. Wielki przewodnik, t. 8: Zawale, Tarnów 2001, s. 13-49.

Komorowski W., Tarnowski węzet kolejowy. Historia i architektura, „Rocznik Tarnowski” 1991/1992, s. 125-132.

Komorowski W., Tarnowski węzet kolejowy. Historia i architektura [w:] Tarnów. Wielki przewodnik, t. 19: Strusina, Tarnów 2009, s. 317-331.

Leniek J., Herzig F., Leśniak F., Dzieje miasta Tarnowa, Tarnów 1911.

Majorek C., Marmon W., Oświata i kultura regionu tarnowskiego w okresie rozbiorów i niewoli. Rozwój szkolnictwa ludowego i pedagogicznego [w:] Tarnów. Dzieje miasta i regionu, t. 2: Czasy rozbiorów i Drugiej Rzeczypospolitej, red. F. Kiryk, Z. Ruta, Tarnów 1983. 
Pikul S., Olszówka W., Tarnowskie Wodociagi (II) [w:] Tarnów. Wielki przewodnik, t. 19: Strusina, Tarnów 2009, s. 41-50.

Potępa S., Tramwaje (25 września 1911-1939) [w:] Tarnów. Wielki przewodnik, t. 14: Grabówka, Tarnów 2006, s. 191-198.

Ruta Z., Oświata i kultura regionu tarnowskiego w okresie rozbiorów i niewoli. Szkolnictwo średnie i ogólnokształcace [w:] Tarnów. Dzieje miasta i regionu, t. 2: Czasy rozbiorów i Drugiej Rzeczypospolitej, red. F. Kiryk, Z. Ruta, Tarnów 1983.

Simche Z., Tarnów i jego okolica, Tarnów 1993 (reprint wydania z 1930 r.).

Skoraszewski W., Wodociagi (I) [w:] Tarnów. Wielki przewodnik, t. 15: Grabówka, Tarnów 2007, s. 7-10.

Sokol W., Geschichte des k. und k. Feldjäger-Bataillons Nr. 13., Bochnia 1899.

Sterkowicz C., Elektrownia. Zakład Energetyczny w Tarnowie [w:] Tarnów. Wielki przewodnik, t. 15: Grabówka, Tarnów 2007, s. 185-194.

Szczepanik W., Cesarskie dzieci z Tarnowa. 57. galicyjski pułk piechoty $w$ latach 18941918, Kraków 2011.

Szuro S., Informator statystyczny do dziejów społeczno-gospodarczych Galicji. Koleje żelazne w Galicji w latach 1847-1914, Kraków 1997.

Szuro S., Informator statystyczny do dziejów społeczno-gospodarczych Galicji. Ludność wojskowa Austro-Węgier rekrutująca się i stacjonująca na terenie Galicji 1869-1913, Kraków-Warszawa 1990, t. 284.

Szymczak-Hoff J., Życie towarzyskie i kulturalne Rzeszowa $w$ dobie autonomii Galicji, Rzeszów 1993.

Tyrowicz M., Tarnów i region tarnowski w dobie walk o wolność społeczna i narodowa [w:] Tarnów. Dzieje miasta i regionu, t. 2: Czasy rozbiorów i Drugiej Rzeczypospolitej, red. F. Kiryk, Z. Ruta, Tarnów 1983.

Tyrowicz M., Łopuszański B., Ziemia tarnowska w okresie przedautonomicznym [w:] Tarnów. Dzieje miasta i regionu, t. 2: Czasy rozbiorów i Drugiej Rzeczypospolitej, red. F. Kiryk, Z. Ruta, Tarnów 1983.

Zdrada J., Tarnów pod zaborem austriackim, cz. II (1848-1918). Rozwój gospodarczy Tarnowa [w:] Tarnów. Wielki przewodnik, t. 4, Tarnów 1997, s. 114-130.

Zdrada J., Ziemia tarnowska w okresie autonomii galicyjskiej 1849-1918 [w:] Tarnów. Dzieje miasta i regionu, t. 2: Czasy rozbiorów i Drugiej Rzeczypospolitej, red. F. Kiryk, Z. Ruta, Tarnów 1983. 